\title{
The Effect of Psychoactive Drugs on in vitro Platelet Function
}

\author{
Angelika Schedel Sophia Thornton Harald Klüter Peter Bugert \\ Institute of Transfusion Medicine and Immunology, Medical Faculty Mannheim, University of Heidelberg, German Red Cross Blood Service \\ of Baden-Württemberg - Hessen, Mannheim, Germany
}

\section{Keywords}

Whole blood platelet aggregation .

Impedance aggregometry · Neuroactive psychoactive drugs · Neuronal receptors

\section{Summary}

Background: Neuro-hormonal and hemostatic mechanisms are important in a wide range of psychological and cardiovascular diseases. The use of psychoactive drugs in mental illnesses is often involved with hematologic side effects including impaired platelet function. Subsequently, the risk for the development of cardiovascular diseases may be higher in these patients. Interestingly, platelets that play a key role in cardiovascular complications contain quite a number of neuronal receptors which are involved in psychotic disorders. It has been widely discussed whether psychoactive drugs used in the therapy of psychotic disorders have a direct effect on platelet function and whether the effects are transmitted through the corresponding receptors on the platelet surface. Material and Methods: In this study, we tested several psychoactive drugs regarding their impact on whole blood platelet aggregation. Results: Antidopaminergics preferentially inhibited ADP-induced aggregation whereas anticholinergics mainly inhibited U46619induced aggregation. Because platelets respond selectively to different psychoactive drugs we assume that corresponding receptors have a functional aspect on platelets and that receptor blockade affects platelet aggregation through different mechanisms. Conclusion: The knowledge about the effects of psychoactive drugs on platelet function may help to characterize neuronal receptors on platelets and may contribute to a better understanding of altered platelet function during therapy with psychoactive drugs.

\section{Schlüsselwörter}

Vollblutthrombozytenaggregation Impedanzaggregometrie - Neuroaktive psychoaktive Medikamente $\cdot$ Neuronale Rezeptoren

\section{Zusammenfassung}

Hintergrund: Neurohormonale und hämostatische Mechanismen sind für die Entstehung zahlreicher psychologischer und kardiovaskulärer Erkrankungen von großer Bedeutung. Zahlreiche Studien der letzten Jahre belegen, dass die Behandlung mentaler Erkrankungen mit psychoaktiven Medikamenten mit Thrombozytenfunktionsstörungen einhergehen kann. Folglich könnte bei diesen Patienten das Risiko für die Entstehung von kardiovaskulären Erkrankungen steigen. Interessanterweise verfügen Thrombozyten, die bei der Entstehung kardiovaskulärer Komplikationen von zentraler Bedeutung sind, über eine Vielzahl von Rezeptoren, die funktionell an psychotischen Störungen beteiligt sind. Seit längerem wird diskutiert, ob psychoaktive Substanzen, die in der Therapie psychotischer Störungen eingesetzt werden, einen direkten Einfluss auf die Thrombozytenfunktion haben und ob die Effekte eventuell durch die entsprechenden Rezeptoren vermittelt werden. Material und Methoden: In der vorliegenden Studie haben wir den Einfluss verschiedener psychoaktiver Substanzen auf die Thrombozytenaggregation im Vollblut getestet. Ergebnisse: Antidopaminerge Substanzen inhibierten signifikant die ADP-induzierte Aggregation, während anticholinerge Substanzen hauptsächlich die durch Thromboxan $A_{2}$ (U46619) induzierte Aggregation hemmten. Da die Thrombozyten also selektiv unterschiedlich auf die Substanzen reagieren, ist zu vermuten, dass die entsprechenden Rezeptoren bei den Thrombozyten vorhanden sind und deren Blockierung sich durch unterschiedliche Mechanismen auf die Thrombozytenaktivierung auswirkt. Schlussfolgerung: Die Erkenntnisse über die Wirkung psychoaktiver Substanzen auf die Thrombozytenfunktion können sowohl zur funktionellen Charakterisierung neuronaler Rezeptoren bei Thrombozyten als auch zum Verständnis veränderter Thrombozytenfunktion während der Therapie mit psychoaktiven Substanzen beitragen.

\begin{tabular}{|c|c|}
\hline KARGER & (C) 2010 S. Karger GmbH, Freiburg \\
\hline $\begin{array}{l}\text { Fax +49 } 7614520714 \\
\text { Information@Karger.de } \\
\text { www.karger.com }\end{array}$ & $\begin{array}{l}\text { Accessible online at: } \\
\text { www.karger.com/tmh }\end{array}$ \\
\hline
\end{tabular}

Prof. Dr. Peter Bugert

Institut für Transfusionsmedizin und Immunologie

DRK-Blutspendedienst Baden-Württemberg - Hessen gGmbH

Friedrich-Ebert-Straße 107, 68167 Mannheim, Germany

Tel. +49 621 3706-9495, Fax -9496

peter.bugert@medma.uni-heidelberg.de 


\section{Introduction}

Epidemiologic, clinical, and laboratory studies have repeatedly demonstrated a relationship between the cardiovascular system and stress, psychological symptoms, and psychiatric disorders $[1,2]$. The use of psychoactive drugs in mental illnesses is often involved with hematologic side effects including impaired platelet function [3]. Many neuronal molecules and receptors, which are involved in the neuronal mechanism of mental diseases, have also been shown to be involved in platelet function. These include G-protein-coupled receptors (GPCRs), e.g. serotonin, catecholamine, and tachykinin receptors, and as recently demonstrated those which form ion channels, e.g. glutamate receptors [4-6]. Most of the knowledge about the non-neuronal system on platelets comes from their use as a peripheral model for the investigation of the efficacy of psychoactive drugs in mental illnesses [2, 7]. In this respect, it has been a long discussion whether the effects of psychoactive drugs on platelet function are rather caused by unspecific membrane disturbance than by specific binding to corresponding receptors on platelets $[2,7]$.

Platelets express a complete and functional dopaminergic system including the dopamine transporter (DAT) and dopamine receptors $[8,9]$. Recently, we showed that dopamine can potentiate ADP-induced platelet microaggregate adhesion through D2-like dopamine receptors [10]. A number of D2like dopamine receptor antagonists, e.g. clozapine and raclopride, are currently in use for the treatment of schizophrenic patients. An association between D2-like dopamine receptor antagonists and modulation of platelet function was frequently reported, and most of these in vivo reports concern clozapine $[11,12]$. A relationship between D2-like receptors and depression has recently been reviewed [13].

The effect of cholinergic drugs on platelet function has not been reported, up until now. Most of the cholinergic molecules target nicotinic ion channels including the noncompetitive antagonist mecamylamine [14]. Mecamylamine has been clinically used for the treatment of hypertension, depression, autism, and alcohol abuse. Furthermore, in developing smoking cessation strategies, mecamylamine has been shown to be useful when co-administered with transdermal nicotine [15-18]. In line with this, the opioid receptor inhibitor naltrexone, a well-known competitive narcotic antagonist used in the maintenance treatment of acute opioid intoxications, was also reported to be a beneficial coadjuvant in smoking cessation programs [19]. Interestingly, naltrexone was shown to suppress platelet aggregation in former heroin addicts [20].

These reports and the increasing knowledge about functional neuronal receptors on platelets encouraged us to investigate the effect of psychoactive molecules on ex vivo platelet function. We investigated psychoactive drugs of the dopaminergic system known to modulate platelet function and cholinergic drugs including the anti-opioid (naltrexone). These have not been investigated up until now for this purpose. Using the Multiplate ${ }^{\mathrm{TM}}$ analyzer, we measured platelet aggregation in whole blood of healthy, non-smoking volunteers. Platelet activation via different receptors and signaling pathways was achieved by application of classical platelet agonist ADP $\left(\mathrm{P} 2 \mathrm{Y}_{12} / \mathrm{P}_{2} \mathrm{Y}_{2}\right.$ receptors and $\mathrm{G}_{\mathrm{i}} / \mathrm{G}_{\mathrm{q}}$ protein signaling) and $\mathrm{U} 46619$ (thromboxane $\mathrm{A}_{2}$ receptor and $\mathrm{G}_{\mathrm{q}}$ protein signaling) $[21,22]$. In order to prove the suitability of the testing method used, we also applied the calcium channel blocker verapamil since its antiplatelet effect is well documented in literature [23].

\section{Material and Methods}

\section{Drugs and Chemicals}

ADP (ADPtest, $2.5 \mu \mathrm{mol} / \mathrm{l}$ ) was purchased from Dynabyte (Munich, Germany). U46619, S(-)-raclopride (+)-tartrate salt, clozapine, mecamylamine hydrochloride, and naltrexone hydrochloride were from Tocris Bioscience (Ellisville, MI, USA). Verapamil hydrochloride, methyllycaconitine (MLA) citrate, and atropine were from Sigma-Aldrich (Taufkirchen, Germany).

\section{Multiple Electrode Aggregometry}

According to the manufacturer's instructions, recombinant hirudin $(25 \mu \mathrm{g} / \mathrm{ml})$ was used as anticoagulant (hirudin blood collection tubes; Dynabyte, Munich, Germany). Whole blood was donated by 6 healthy, non-smoking individuals, who had not taken any medication known to interfere with platelet function for the last 10 days. The study volunteers gave their informed written consent for using their blood samples for platelet in vitro studies. Platelet aggregation was determined using multiple electrode aggregometry (MEA) on the multichannel Multiplate ${ }^{\mathrm{TM}}$ analyzer (Dynabyte). $300 \mu \mathrm{l}$ of whole blood were added to the MEA test cell and warmed for $3 \mathrm{~min}$ to a temperature of $37^{\circ} \mathrm{C}$. The activator solutions were added and aggregation was measured over a time period of $6 \mathrm{~min}$. For the investigation of psychoactive drugs a blood sample was pre-incubated with the desired substance for $30 \mathrm{~min}$ before applying the sample to aggregometry. The impedance change due to the attachment of platelets to the sensor electrodes was quantified and given as arbitrary units (AU). In order to avoid overstimulation of platelets by exceeding agonist concentrations, the minimal agonist concentration for significant platelet aggregation was determined in foregone pilot experiments for ADP as $2.5 \mu \mathrm{mol} / 1$ and for $\mathrm{U} 46619$ as $0.75 \mu \mathrm{mol} / \mathrm{l}$.

\section{Statistical Analysis}

Each substance was tested in at least 6 healthy individuals. Statistical analysis was performed with $t$ test analysis for paired samples (aggregation without psychoactive drug vs. aggregation with drug) by using SPSS 12.0 statistical software (SPSS, Chicago, IL, USA). P-values $<0.05$ were considered as significant.

\section{Results}

In this study we investigated psychoactive drugs, which either act on GPCRs or calcium channels as described for antidopaminergics and anticholinergics, respectively. In order to evaluate the capability of the Multiplate ${ }^{\mathrm{TM}}$ analyzer to detect antiplatelet effects in vitro, we examined the calcium channel blocker verapamil and the GPCR antagonist clozapine. 
Fig. 1. Effect of psychoactive drugs on U46619-induced platelet aggregation: Whole blood of 6 healthy, non-smoking individuals was pre-incubated for $30 \mathrm{~min}$ with the calcium channel blocker verapamil (VER; $100 \mathrm{nmol} / \mathrm{l}$ ); the antidopaminergics clozapine (CLO; $10 \mu \mathrm{mol} / \mathrm{l}$ ) and raclopride (RAC; $1 \mu \mathrm{mol} / \mathrm{l})$; the anticholinergics atropine (ATR; $1 \mu \mathrm{mol} / \mathrm{l})$, mecamylamine (MECA; $10 \mu \mathrm{mol} / 1)$ and methyllycaconitine (MLA; $100 \mathrm{nmol} / \mathrm{l}$ ), and the antiopioid naltrexone (NE; $25 \mu \mathrm{mol} / \mathrm{l}$ ) prior to stimulation with the classical platelet agonist $\mathrm{U} 46619(0.75 \mu \mathrm{mol} / \mathrm{l})$. All drugs were used in therapeutically relevant concentrations. VER, CLO, MLA, and NE significantly inhibited U46619-induced platelet aggregation. The other drugs tended also to inhibit platelet aggregation which, however, did not reach statistical significance.
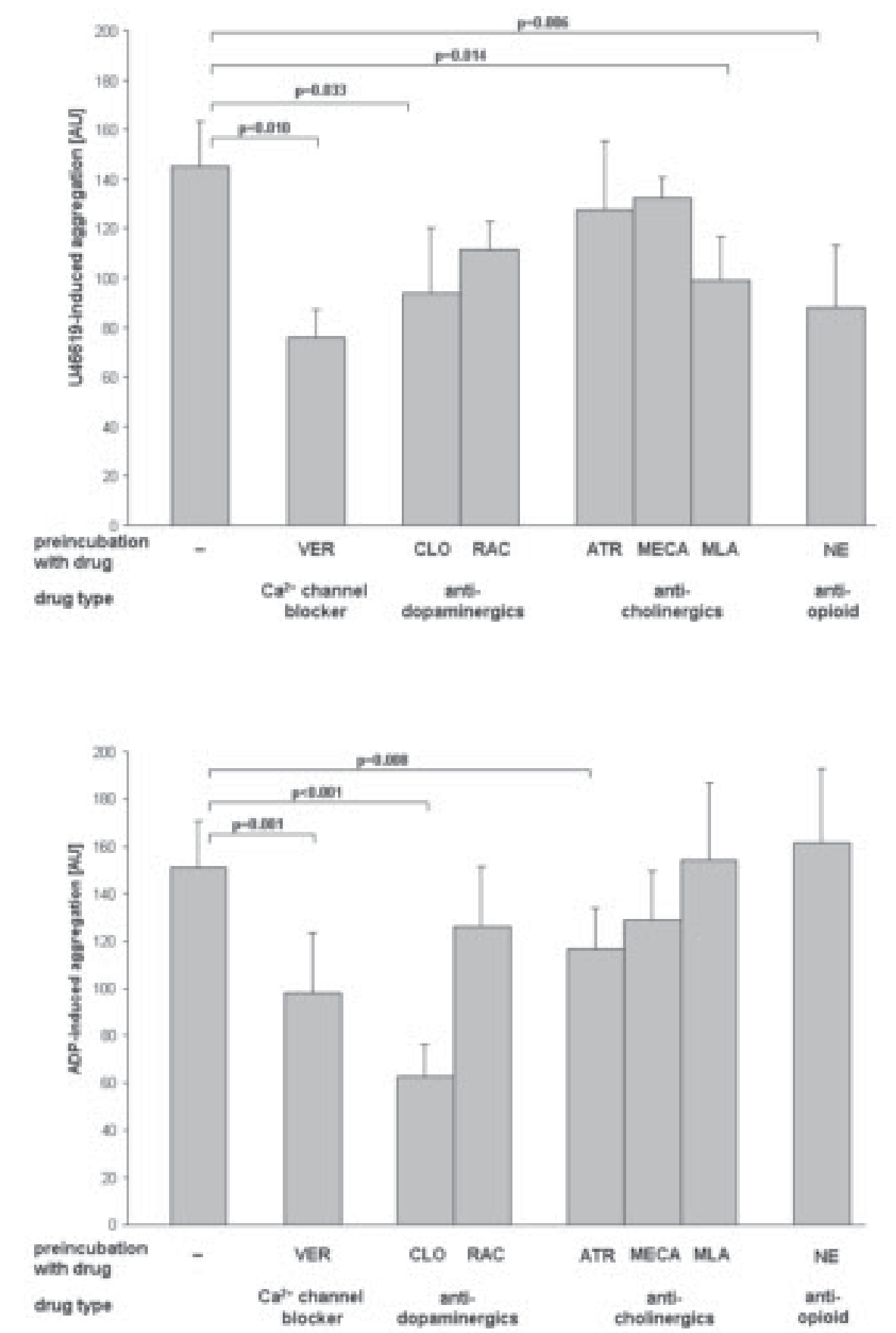

Fig. 2. Effect of psychoactive drugs on ADPinduced platelet aggregation: Whole blood of 6 healthy, non-smoking individuals was pre-incubated for $30 \mathrm{~min}$ with the calcium channel blocker verapamil (VER; $100 \mu \mathrm{mol} / \mathrm{l})$; the antidopaminergics clozapine (CLO; $10 \mu \mathrm{mol} / \mathrm{l})$ and raclopride (RAC; $1 \mu \mathrm{mol} / \mathrm{l})$; the anticholinergics atropine (ATR; $1 \mu \mathrm{mol} / \mathrm{l}$ ), mecamylamine (MECA; $10 \mu \mathrm{mol} / \mathrm{l}$ ) and methyllycaconitine (MLA; $100 \mathrm{nmol} / \mathrm{l}$ ), and the anti-opioid naltrexone (NE; $25 \mu \mathrm{mol} / \mathrm{l})$ prior to stimulation with the classical platelet agonist ADP $(2.5 \mu \mathrm{mol} / \mathrm{l})$. All drugs were used in therapeutically relevant concentrations. VER, CLO, and ATR significantly inhibited ADP-induced platelet aggregation. The other drugs tended also to inhibit platelet aggregation which, however, did not reach statistical significance.

\section{Effect of Verapamil on Whole Blood Platelet Aggregation}

The antiplatelet action of verapamil is well documented in the literature [23]. Pre-treatment of whole blood with a rather low concentration of verapamil $(100 \mathrm{nmol} / \mathrm{l})$ resulted in a significant inhibition of U46619-induced platelet aggregation $(145 \pm 18$ AU to $76 \pm 11$ AU; $p=0.01$; fig. 1$)$ but not ADPinduced aggregation (data not shown). However, at a 1,000fold higher concentration of verapamil $(100 \mu \mathrm{mol} / \mathrm{l})$, the ADP-induced aggregation was also inhibited $(151 \pm 18 \mathrm{AU}$ to $98 \pm 25$ AU; $p=0.001$; fig. 2).

\section{Effect of Antidopaminergics on Whole Blood Platelet Aggregation}

In previous studies, our group identified dopamine D2-like receptors to be involved in ADP-mediated platelet activation [10]. Therefore, we expected dopamine D2-like antagonists to affect ADP-induced platelet aggregation. We tested the D2-like receptor antagonists, clozapine and raclopride, on ADP- and U46619-induced platelet aggregation. As expected, ADP-stimulated aggregation was significantly inhibited by clozapine at $10 \mu \mathrm{mol} / 1$ (to $63 \pm 13 \mathrm{AU} ; \mathrm{p}<0.001$; fig. 2). Raclopride at $1 \mu \mathrm{mol} / \mathrm{l}$ tended to inhibit aggregation 
Table 1. Psychoactive drugs and their effects on in vitro platelet aggregation: summary of the study results

\begin{tabular}{|c|c|c|c|c|c|}
\hline Substance group & Substance & Receptor specificity & Clinical use & $\begin{array}{l}\text { Inhibition of U46619- } \\
\text { induced aggregation* }\end{array}$ & $\begin{array}{l}\text { Inhibition of ADP- } \\
\text { induced aggregation* }\end{array}$ \\
\hline L-Type channel blocker & verapamil & L-Type Ca2+ channels & $\begin{array}{l}\text { hypotension, } \\
\text { cardiac arrhythmia }\end{array}$ & + & ++ \\
\hline Antidopaminergics & clozapine & $\begin{array}{l}\text { D2-like dopamine } \\
\text { receptors }\end{array}$ & schizophrenia & + & ++ \\
\hline Antidopaminergics & raclopride & $\begin{array}{l}\text { D2-like dopamine } \\
\text { receptors }\end{array}$ & schizophrenia & - & - \\
\hline Anticholinergics & atropine & muscarinic AChRs & anesthesia & - & ++ \\
\hline Anticholinergics & mecamylamine & nicotinic AChRs & $\begin{array}{l}\text { alcohol dependence, } \\
\text { smoking cessation }\end{array}$ & - & - \\
\hline Anticholinergics & methyllycaconitine & nicotinic AChRs & in clinical trials & + & - \\
\hline Anti-opioids & naltrexone & opioid receptors & $\begin{array}{l}\text { alcohol dependence, } \\
\text { smoking cessation }\end{array}$ & ++ & - \\
\hline
\end{tabular}

*Inhibitory effects of psychoactive drugs on U46619- or ADP-induced platelet aggregation were significant $(+: \mathrm{p}<0.05 ;++: \mathrm{p}<0.01)$ or not detectable $(-: \mathrm{p}>0.05)$.

$\mathrm{AChR}=$ Acetylcholine receptor.

which did not reach significance (to $126 \pm 25$ AU; $\mathrm{p}=0.1$ ). Similarly, U46619-induced aggregation was significantly inhibited by clozapine (to $94 \pm 26$; $\mathrm{p}=0.033$ ), whereas raclopride had no effect (fig. 1).

\section{Effect of Anticholinergics on Whole Blood Platelet Aggregation}

The non-competitive nicotinic antagonist mecamylamine at $10 \mu \mathrm{mol} / \mathrm{l}$ did not affect platelet aggregation induced by both agonists. Therefore, we additionally tested the competitive nicotinic antagonist MLA, which is used as a structural prototype for the identification of novel cholinergic drugs [24]. Pre-incubation of whole blood with MLA at $100 \mathrm{nmol} / \mathrm{l} \mathrm{sig-}$ nificantly lowered platelet aggregation induced by U46619 (to $99 \pm 17$ AU; $p=0.014$; fig. 1 ), but not ADP-induced aggregation. Atropine, a non-selective competitive cholinergic antagonist, acts on muscarinic G-protein-coupled acetylcholine receptors. After pretreatment of whole blood with $1 \mu \mathrm{mol} / \mathrm{l}$ atropine, a significantly lower ADP-induced platelet aggregation was seen (to $116 \pm 18 \mathrm{AU} ; \mathrm{p}=0.008$ ), whereas U46619induced aggregation was not affected.

\section{Effect of an Anti-Opioid on Whole Blood Platelet Aggregation}

The opioid antagonist naltrexone was shown to affect the cholinergic system by binding to cholinergic ion channels [25]. In a previous study, it was shown that long-term treatment of heroin addicts with naltrexone resulted in suppression of ex vivo platelet aggregation [20]. In our in vitro test, we found that naltrexone at a concentration of $25 \mu \mathrm{mol} / 1$ significantly inhibited U46619-induced aggregation (88 \pm 25 AU; $\mathrm{p}=0.006$ ), but had no effect on ADP-induced aggregation.

\section{Discussion}

The results of this study clearly demonstrate that psychoactive drugs of the dopaminergic and the cholinergic type have an influence on platelet function (summarized in table 1). We could also show that whole blood impedance aggregometry (performed by using the Multiplate ${ }^{\mathrm{TM}}$ analyzer) represents a suitable assay to detect drug-induced platelet inhibition. This was demonstrated using the calcium channel blocker verapamil, which has been extensively studied regarding its antiaggregatory effects on platelets [23]. Furthermore, it was reported that low concentrations of verapamil cause inhibition of transmembrane calcium influx, whereas inhibition of ADPinduced calcium mobilization from intracellular stores requires higher concentrations of the drug [26]. In our study, low concentrations of verapamil (100 nmol/l) inhibited U46619-induced aggregation, which could be assigned to transmembrane calcium influx. At a 1,000-fold higher concentration of verapamil, ADP-induced aggregation was also inhibited, which supports previous data [26]. We assume that calcium channel antagonists mainly target U46619-induced platelet aggregation because U46619 at lower concentrations, as used in our study, mainly mediates calcium-related mechanism in platelets.

Although the non-competitive cholinergic antagonist mecamylamine had no effect, the competitive cholinergic antagonist MLA significantly inhibited U46619-induced aggregation, but not the aggregation mediated by ADP. Since MLA is a structural prototype for the identification of novel cholinergic drugs, this inhibitory action of MLA may prove to be important [24]. In addition, the opioid receptor antagonist naltrexone, which was reported to bind to cholinergic ion channels in neurons, also inhibited U46619-induced but not 
ADP-induced aggregation. This suggests an association between ion channels and thromboxane receptor signaling in platelets.

Based on our previous findings on dopamine co-agonism [10], we expected the D2-like receptor antagonist clozapine to inhibit ADP-induced aggregation. Indeed, the most pronounced inhibition by clozapine was seen for ADP-induced aggregation. The D2-like receptor antagonist raclopride showed an inhibitory tendency. Interestingly, the cholinergic antagonist atropine, which targets G-protein-coupled muscarinic acetylcholine receptors inhibited ADP-induced but not U46619-induced platelet aggregation. These results imply that different psychoactive drugs affect different platelet activation pathways. The question arises whether these effects are mediated via direct inhibition of the respective drug receptors on platelets. At least for the dopaminergic system this question can be answered: platelets do possess a complete functional dopaminergic system [8-10], and the inhibitory effect seen by antidopaminergics is very likely a receptor-dependent mechanism. Based on microarray data, we have identified cholinergic receptor gene transcripts in platelets of the nicotinic and the muscarinic type [27-29]. In addition, it has been suggested that platelets store acetylcholine in their granules and acetylcholine esterase is present on platelets [30-31]. Together with our data on platelet inhibition by anticholinergics this indicates a cholinergic system on platelets.
The psychoactive drugs tested in this study are frequently used in the therapy of psychotic disorders. Further knowledge about the effects of the drugs on platelet function may help to understand pathomechanisms that cause a significantly higher risk for the development of cardiovascular disease in patients with psychotic disorders. In addition, our results may be of importance for cardiovascular patients that are under cardiovascular surgery. These patients may be under dual platelet therapy with aspirin and clopidrogel. We suggest close monitoring of platelet function in cardiovascular patients under dual platelet therapy, especially when they are also under treatment with psychotic drugs. The platelet inhibitory properties of anticholinergics may also contribute to the development of new antiplatelet drugs and the identification and characterization of cholinergic receptors on platelets.

\section{Acknowledgement}

We wish to thank Gabriele Rink for expert technical assistance.

\section{Disclosure}

The authors declared no conflict of interest.

\section{References}

$>1$ Nemeroff CB, Musselmann DL, Evans MD: Depression and cardiac disease. Depress Anxiety 1998;8(suppl 1):1-79.

2 Plein H, Berk M: The platelet as a peripheral marker in psychiatric illness. Hum Psychopharmacol Clin Exp 2001;16:229-236.

>3 Oyesanmi O, Kunkel EJS, Monti DA, Field HL: Hematologic side effects of psychotropics. Psychosomatics 1999;40:414-421.

4 Anfossi G, Trovati M: Role of catecholamines in platelet function: pathophysiological and clinical significance. Eur J Clin Inv 1996;26:353-370.

$\checkmark 5$ Graham GJ, Stevens JM, Page NM, Grant AD, Brian SD, Lowry PJ, Gibbins JM: Tachykinins regulate the function of platelets. Blood 2004;104: 1058-1065.

6 Morrell CN, Sun H, Ikeda M, Beique JC, Swaim AM, Mason E, Martin TV, Thompson LE, Gozen O, Ampagoomian D, Sprengel R, Rothstein J, Faraday N, Huganir R, Lowenstein CJ: Glutamate mediates platelet activation through the AMPA receptor. J Exp Med 2008;205:575-584.

7 Bakken AM, Staeffler A, Jorgensen HA, Holmsen $\mathrm{H}$ : Glycerophospholipid molecular species in platelets and brain tissues - are platelets a good model for neurons? Platelets 2006;17:484-492.

8 Ricci A, Bronzetti E, Mannino F, Mignini F, Morosetti C, Tayebati S, Amenta F: Dopamine receptors in human platelets. Naunyn Schmiedebergs Arch Pharmacol 2001;363:376-382.

9 Frankhauser P, Grimmer Y, Bugert P, Deuschle M, Schmidt M, Schloss P: Characterization of the neuronal dopamine transporter DAT in human blood platelets. Neurosci Lett 2006;399:197-201.
10 Schedel A, Schloss P, Klueter H, Bugert P: The dopamine agonism on ADP-stimulated platelets is mediated through D2-like but not D1-like dopamine receptors. Naunyn Schmiedebergs Arch Pharmacol 2008;378:431-439.

11 Durst R, Dorevitch A, Fraenkel Y: Platelet dysfunction associated with clozapine therapy. South Med J 1993;86:1170-1172.

12 Hägg S, Spigset O, Söderström TG: Association of venous thromboembolism and clozapine. Lancet 2000;355:1155-1156.

13 Gershon AA, Vishne T, Grunhaus L: Dopamine D2-like receptors and the antidepressant response. Biol Psychiatry 2007;61:145-153.

14 Lindström JM: Nicotinic acetylcholine receptors; in North RA (ed): Handbook of Receptors and Channels. Boca Raton, FL, CRC Press, 1995, pp 153-175.

15 Shytle RD, Silver AA, Lukas RJ, Newman MB, Sheehan DV, Sanberg PR: Nicotinic acetylcholine receptors as targets for antidepressants. Mol Psychiatry 2002;7:525-535.

16 Lippiello PM: Nicotinic cholinergic antagonists: a novel approach for the treatment of autism. Med Hypotheses 2005;66:985-990.

17 Blomqvist O, Hernandez-Avila CA, Van, Kirk J, Rose JE, Kranzler HR: Mecamylamine modifies the pharmacokinetics and reinforcing effects of alcohol. Alcohol Clin Exp Res 2002;26:326-333.

18 Buchhalter AR, Fant RV, Henningfield JE: Novel pharmacological approaches for treating tobacco dependence and withdrawal. Drugs 2008;68:10671088 .
19 Hutchison KE, Monti PM, Rohsenow DJ, Swift RM, Colby SM, Gnys M, Niaura RS, Sirota AD: Effects of naltrexone with nicotine replacement on smoking cue reactivity: preliminary results. Psychopharmacology 1999;142:139-143.

20 Garcia-Sevilla JA, Ulibarri I, Giralt MT, Areso P, Oliveros RG, Gutierrez M: Chronic naltrexone suppresses platelet aggregation induced by adrenaline and 5-hydroxytryptamine in former heroin addicts. J Neural Transm 1988;73:157-160.

21 Daniel JL, Dangelmaier C, Jin J, Ashby B, Smith JB, Kunapuli SP: Molecular basis for ADP-induced platelet activation, I: evidence for three distinct ADP receptors on human platelets. J Biol Chem 1998;273:2024-2029.

22 Paul BZS, Jin J, Kunapuli SP: Molecular mechanism of thromboxane A2-induced platelet aggregation. J Biol Chem 1999;274:29108-29114.

23 Hjemdahl P, Wallen NH: Calcium antagonist treatment, sympathetic activity and platelet function. Eur Heart J 1997;18:A36-A50.

24 McKay DB, Chang C, González-Cestari TF, McKay SB, El-Hajj RA, Bryant DL, Zhu MX, Swaan PW, Arason KM, Puliplaka AB, Orac CM, Bergmeier SC: Analogs of methyllycaconitine as novel noncompetitive inhibitors of nicotinic receptors: pharmacological characterization, computational modelling, and pharmacophore development. Mol Pharmacol 2007;71:1288-1297. 
25 Almeida LEF, Pereira EFRP, Alkondon M, Fawcett WP, Randall WR, Albuquerque EX: The opioid antagonist naltrexone inhibits activity and alters expression of $\alpha 7$ and $\alpha 4 \beta 2$ nicotinic receptors in hippocampal neurons: implications for smoking cessation programs. Neuropharmacology 2000;39:2740-2755.

26 Mehta JL: Influence of calcium-channel blockers on platelet function and arachidonic acid metabolism. Am J Cardiol 1985;55:158B-164B.
27 Bugert P, Dugrillon A, Günaydin A, Eichler H Klüter $\mathrm{H}$ : Messenger RNA profiling of human platelets by microarray hybridization. Thromb Haemost 2003;90:748-758.

28 Bugert P, Klüter H: Profiling of gene transcripts in human platelets: an update of the platelet transcriptome. Platelets 2006;17:503-504.

29 Bugert P, Ficht M, Klüter H: Towards the identification of novel platelet receptors: comparing RNA and proteome approaches. Transfus Med Hemother 2006;33:236-243.
30 Wessler I, Kirkpatrick CJ, Racke K: Non-neuronal acetylcholine, a locally acting molecule, widely distributed in biological systems: expression and function in humans. Pharmacol Ther 1998;77:59-79.

1 Chuang HY: Cholinesterase activities of intact platelets as measured by an improved radiometric method. Biochim Biophys Acta 1973;321:546-552. 